Lemburg, P.: Efficiency of heparin in the treatment of newborn infants with respiratory distress syndrome and disseminated intravascular coagulation. Eur. J. Pediatr., 47: 133 (1980).

15. Hambleton, G. and Aplleyard, W. J.: Controlled trial of fresh frozen plasma in asphyxiated low birth weight infants. Arch. Dis. Child., 48: 31 (1973).

16. Harrison, V. C., de Heese, V., and Klein, M.: Intracranial hemorrhage associated with hyaline membrane disease. Arch. Dis. Child., 43: 116 (1968).

17. Hathaway, W. E., Müll, M. M., and Pechet, G. S.: Disseminated intravascular coagulation in the newborn. Pediatrics, 43: 233 (1969)

18. Hathaway, W. E., Mahasandana, Ch., and Makowski, E. L.: Cord blood coagulation in infants of high risk pregnant women. Am. J. Obstet. Gynaecol., 51: 121 (1974).

19. Hurlet-Birk Jensen, A., Josso, F., Zamet, P., Monset-Chouchard, M., and Minkowski, A.: Evolution of blood clotting factor levels in premature infants during the first 10 days of life: A study of 96 cases with comparison between clinical status and blood clotting factor levels. Pediatr. Res., 7: 638 (1973).

20. Kahlé, L. H., Schipper, H. G., Jenkins, C. S. P., and Ten Cate, J. W.: Antithrombin III. I. Evaluation of an automated antithrombin III method. Thromb. Res., 12: 1003 (1978).

21. Mahasandana, Ch. and Hathaway, W. E.: Circulating anticoagulants in the newborn: Relation to hypercoagulability and the Idiopathic Respiratory Distress Syndrome. Pediatr. Res., 7: 670 (1973).

22. Markarian, M., Githens, J. H., Rosenblüt, E., Fernandez, F., Jackson, J., Bannon, A. E., Lindley, A., Lubchenco, L. O., and Martorell, R.: Hypercoagulability in premature infants with special reference to the Respiratory Distress Syndrome and Hemorrhage 1. coagulation studies. Biol. Neon., 17: 84 (1971).

23. Markarian, M., Lubchenco, L. O., Rosenblüt, E., Fernandez, F., Lang, D. Jackson, J. J., Bannon, A. E., Lindley, A., Githens, J. H., and Martorell, R.: Hypercoagulability in premature infants with special reference to the respiratory distress syndrome and hemorrhage. II. The effect of heparin. Biol. Neonate, 17: 98 (1971)

24. Peters, M., Breederveld, C., Kahlé, L. H., and Ten Cate, J. W.: Rapid microanalysis of coagulation parameters by automated chromogenic substrated methods-application in neonatal patients. Thromb. Res., 28: 773 (1982).

25. Prociany, R. S., Garcia-Prats, J. A., Adams, J. M., Silvers, A., and Rudolph, A. J.: Hyaline membrane disease and intraventricular hemorrhage in small for gestational age infants. Arch. Dis. Child., 55: 502 (1980).

26. Schipper, H. G., Roos, J., van der Meulen, F., and Ten Cate, J. W. Antithrombin III deficiency in surgical intensive care patients. Thromb. Res., 73: 73 (1981).

27. Schipper, H. G., Kahlé, L. H., Jenkins, C. S. P., and Ten Cate, J. W. Antithrombin III transfusion in disseminated intravascular coagulation. Lancet, 2: 854 (1978)

28. Schipper, H. G. and Ten Cate, J. W.: Antithrombin III transfusion in patients with liver cirrhosis. Brit. J. Haematol., 52: 25 (1982)

29. Setzer, E. S., Webb, J. B., Wassenaar, J. W., Reeder, J. D., Metha, P. S., and Eitzman, D. V.: Platelet dysfunction and coagulopathy in intraventricular hemorrhage in the premature infant. J. Pediatr., 100: 599 (1982)

30. Van Wijk, E. M., Kahlé, L. H., and Ten Cate, J. W.: The automted amidolytic techniques for the determination of factor $\mathrm{X}$ and factor $\mathrm{X}$ antigen: application to patients. Clin. Chem., 1: 885 (1980).

31. Volpe, J. J.: Neonatal intraventricular hemorrhage. N. Eng. J. Med., 304: 886 (1981).

32. Wade-Evans, T.: Thrombin in the hepatic sinusoids of the neborn and their relation to pulmonary hyaline membrane formation. Arch. Dis. Child., 35: $286(1960)$

33. Watkins, M. N., Swan, S., Caprini, J. A., Gardner, Th. H., Zuckerman, L. and Vagher, P.: Coagulation changes in the newborn with respiratory failure. Thromb. Res., 17: 153 (1980)

34. Weissbach, G., Domula, M., Lenk, H., and Schneider, P.: The progressive antithrombin activity and its relation to other factors of the coagulation system in newborns. Acta. Pediatr. Scand., 67: 555 (1974)

35. This study was approved by the Committee of Ethics of the Academic Hospital, University of Amsterdam.

36. The authors are grateful to Prof. W. E. Hathaway and Dr. M. M. McDonald for critically reviewing this manuscript and to Dr. J. Bovill for statistical advices. This investigation was supported by grants from the Astma Foundation Nr. 32.80.21 and Foundtion "De Drie Lichten."

37. Requests for reprints should be addressed to: Dr. M. Peters, Division of Hemostasis and Thrombosis, Academic Medical Centre, Meibergdreef 9 1105 A2 Amsterdam, The Netherlands.

38. Received for publication February 21, 1983

39. Accepted for publication September 8,1983

\title{
Glucose Turnover Rates in Chronically Catheterized Non-Pregnant and Pregnant Rabbits
}

\author{
WILLIAM W. HAY, JR., ${ }^{(16,18)}$ MARC GILBERT, ROBERT L. JOHNSON, ${ }^{(17)}$ AND \\ FREDERICK C. BATTAGLIA \\ Division of Perinatal Medicine, Departments of Pediatrics and Obstetrics/Gynecology, University of Colorado \\ School of Medicine, Denver, Colorado, USA
}

\section{Summary}

Glucose turnover rates have been measured in conscious, chronically catheterized, non-pregnant and pregnant rabbits. Non-pregnant rabbits were studied weekly for 4 wk. Pregnant animals were studied once while non-pregnant and then weekly for up to 4 wk during pregnancy. Glucose turnover rate was measured using a primed-constant infusion of $\left[\mathrm{U}-{ }^{14} \mathrm{C}\right]$ glucose and $\left[6-{ }^{3} \mathrm{H}\right]$ glucose.

The weight of the rabbits did not vary throughout the 4-5 wk of study in either the non-pregnant or pregnant group. Seven pregnant rabbits delivered pups which weighed an average of 61 g each.

In non-pregnant rabbits, blood glucose concentration did not vary with time. In the pregnant rabbits, blood glucose concentration fell by the end of gestation to an average value of $74.6 \pm 2.7$ $\mathrm{mg} / \mathrm{dl}$, significantly less $(P<\mathbf{0 . 0 1})$ than the glucose concentration in the same animals before pregnancy, $88.2 \pm 2.4 \mathrm{mg} / \mathrm{dl}$.

The weight specific glucose turnover rate did not vary with time in either the non-pregnant $\left(4.38 \pm 0.16 \mathrm{mg} \cdot \mathrm{min}^{-1} \cdot \mathrm{kg}^{-1}\right)$ or pregnant rabbits $\left(3.89 \pm 0.29 \mathrm{mg} \cdot \mathrm{min}^{-1} \cdot \mathrm{kg}^{-1}\right)$. Blood glucose clearance did not change over time in the non-pregnant rabbits but did increase in the pregnant rabbits in late pregnancy. Blood glucose clearance was inversely related to the fall in blood glucose concentration.

Glucose turnover rates have been measured during late pregnancy in sheep, guinea pigs, rats, and women. In sheep, weightspecific glucose turnover rates for twin-pregnant ewes have been reported to average nearly $30 \%$ higher than for non-pregnant ewes (2). In pregnant guinea pigs studied over the last half of 
pregnancy, glucose turnover rate was reported to increase progressively to a value at term about twice the rate for non-pregnant females (7). Similarly, in humans, the absolute glucose turnover rate was about $15 \%$ higher in late gestation compared with estimated values for non-pregnant women (10). In both guinea pigs and humans the weight specific glucose turnover rate at the end of pregnancy was not different from values in the nonpregnant state. In none of the above studies was the same animal or woman studied in the non-pregnant state and then sequentially during gestation; thus, assessment of the impact of pregnancy on maternal glucose metabolism depended upon interanimal comparisons of glucose turnover rates performed in nonpregnant animals and animals of different gestational age.

In order to study metabolic changes that occur in an animal with pregnancy, we have studied the chronically catheterized female rabbit. The rabbit has some distinct advantages for such metabolic studies over the duration of pregnancy. The animal is large enough for chronic catheterization and repeated blood sampling. The length of a rabbit's gestation is only $31 \mathrm{~d}$ and the animals can be easily bred by artificial insemination permitting accurate timing of gestation.

This report presents data on glucose turnover rates in healthy, conscious, chronically catheterized rabbits. Sequential glucose turnover rates at weekly intervals in non-pregnant female rabbits are compared with similar studies in rabbits which were studied when non-pregnant and then weekly throughout pregnancy.

\section{MATERIALS AND METHODS}

Studies were performed in 22 female New Zealand albino rabbits obtained from a commercial breeder. The rabbits were handled daily, in a gentle manner, by the same three persons. The rabbits were kept in standard stainless steel cages which were darkened by drapes except at the front. Studies and sampling were performed with the rabbit in this same cage or, after adaptation, in an $8 \times 8 \times 16$-inch plastic tray open at the top. No attempt was made to restrain the rabbits. These careful methods of handling were necessary to ensure stability of the rabbit for chronic, stress-free studies. In this regard, the rabbit poses a unique challenge for careful chronic handling quite unlike the guinea pig, which tolerates movement and handling without significant difficulty (15). The rabbits were allowed an ad libitum diet of water and commercial rabbit food (alfalfa pellets).

Surgery was performed after $1 \mathrm{wk}$ of cage adaptation. The rabbits were anesthetized with ketamine $\mathrm{HCl}\left(35 \mathrm{mg} \cdot \mathrm{kg}^{-1} \mathrm{IM}\right)$ and xylazine $\mathrm{HCl}\left(6 \mathrm{mg} \cdot \mathrm{kg}^{-1} \mathrm{IM}\right)$. Twenty gauge polyvinyl catheters were inserted into the left ventricle or aorta and the jugular vein through a midline ventral neck incision. The catheters were tunneled subcutaneously to the back of the neck and exteriorized into a plastic cup with a removable cap. The cup was sutured to the skin. Catheters were flushed every $3 \mathrm{~d}$ with heparinized saline $(200 \mathrm{U} / \mathrm{ml})$. The rabbits were allowed to recover from surgery for $5-7 \mathrm{~d}$ before study. Recovery was determined by resumption of normal eating behavior and food intake.

Detailed descriptions of our surgical techniques, effects of handling, surgery, and anesthesia on rabbit metabolism, and the stability of the model during pregnancy (weight change, food intake, eating behavior, hormone concentrations, and metabolic substrate concentrations) have been reported elsewhere (6).

Glucose turnover rate studies were performed weekly in 11 non-pregnant rabbits for up to $4 \mathrm{wk}$. Glucose turnover rate studies were performed in 11 additional rabbits when nonpregnant; these 11 rabbits were then bred by artificial insemination. The rabbits were injected intravenously with $5 \mathrm{mg}$ of pituitary luteinizing hormone (Armour-Baldwin Laboratories, Omaha, NE) and immediately thereafter, $0.5 \mathrm{ml}$ of freshly collected rabbit semen was injected into the vagina. Glucose turnover rate studies were performed in these animals weekly throughout pregnancy.
Glucose turnover rates were determined by a primed-constant infusion technique which provided $0.75 \mu \mathrm{Ci}$ of $\left[6-{ }^{3} \mathrm{H}\right]$ glucose (Amersham, TRA.85) and $0.35 \mu \mathrm{Ci}$ of $\left[\mathrm{U}-{ }^{14} \mathrm{C}\right]$ glucose (Amersham, CFB .96) per min. The isotopes were dissolved in normal saline and infused at $0.03 \mathrm{ml} / \mathrm{min}$ through the jugular vein catheter. The prime dose was 30 times the infusion rate. Blood samples were obtained at $0,60,75,90,105$, and $120 \mathrm{~min}$ after the start of the infusion. Preliminary experiments confirmed that a steady state specific activity of glucose in the plasma was established by $60 \mathrm{~min}$. Turnover rates at steady state were calculated from the formula $R=F / S$.A., where $R$ is the turnover rate of glucose in the whole blood, $F$ is the infusion rate of radiolabeled glucose in $\mathrm{dpm} / \mathrm{min}$, and S.A. is the whole blood specific activity of glucose in $\mathrm{dpm} / \mathrm{mg}$ at steady state. The metabolic clearance of glucose was calculated as the ratio R/ (GLC) where (GLC) is the whole blood glucose concentration. The percentage of $\left[{ }^{14} \mathrm{C}\right]$ recycling was estimated from the difference between the GTRs simultaneously determined with $\left[6-{ }^{3} \mathrm{H}\right]$ and $\left[\mathrm{U}_{-}{ }^{14} \mathrm{C}\right] \mathrm{glucose}$ :

$$
\% \text { recycling }=\frac{\left[{ }^{3} \mathrm{H}\right] \mathrm{GTR}-\left[{ }^{14} \mathrm{C}\right] \mathrm{GTR}}{\left[{ }^{14} \mathrm{C}\right] \mathrm{GTR}} \times 100
$$

Arterial whole blood samples were deproteinized immediately with barium hydroxide and zinc sulfate and centrifuged for 15 min at $2000 \mathrm{~g}$. An aliquot of the supernatant from each sample was used for the determination of blood glucose concentration using glucose oxidase (Sigma). A second aliquot of the supernate was passed through an ion exchange column (internal diameter, $5 \mathrm{~mm}$ ) containing $2.5 \mathrm{~cm} \mathrm{AG1} \mathrm{X8} \mathrm{formate} \mathrm{resin} \mathrm{above} 2.5 \mathrm{~cm}$ AG50w X8 $\mathrm{H}^{+}$resin. The columns retained greater than $99 \%$ of the amino acids, lactate, and pyruvate. A $1.5-\mathrm{ml}$ water wash eluted greater than $99 \%$ of the glucose from the column. The eluate was evaporated to dryness to remove $\left[{ }^{3} \mathrm{H}_{2} \mathrm{O}\right]$ and redissolved in $1 \mathrm{ml}$ of water before the addition of the scintillation solution ( $\mathrm{PCS}^{\mathrm{TM}}$, Amersham) for counting.

Statistical comparisons among sequential weekly values for weight, food intake, glucose concentration, and for glucose turnover rate were made with a non-paired $t$ test. Linear regression equations for glucose turnover rate versus glucose concentration were derived as the best fit according to testing on a BASIC statistics program using a Cromenco computer. The coefficient of variation for sequential intra-animal measurements was calculated as the mean divided by the standard deviation $\times 100$.

\section{RESULTS}

Eleven non-pregnant and 11 pregnant rabbits were studied. Food intake and eating behavior were identical between the nonpregnant and pregnant groups and did not change during gestation. Over the first $25 \mathrm{~d}$ of pregnancy, food intake remained constant averaging $40 \mathrm{~g} \cdot \mathrm{d}^{-1} \cdot \mathrm{kg}^{-1}$, similar to that measured for the group of non-pregnant rabbits. Food intake was also monitored for $24 \mathrm{~h}$ at 4 -h intervals in the pregnant rabbits. Food intake per animal $\left(12 \mathrm{~g} \cdot 4 \mathrm{~h}^{-1}\right)$ remained almost constant from 4:30 a.m. to $12: 30$ p.m., and then rose progressively until $1: 30$ a.m., when it was about 3-5 times higher than morning values. Weight did not vary significantly throughout the 4-5 wk of study in either the non-pregnant or pregnant group $(P>0.5)$ (Table $1)$. The mean intra-animal coefficient of variation for weight change over time was $3.7 \%$ for the non-pregnant group and $2.1 \%$ for the pregnant group.

Seven rabbits delivered pups which could be counted and weighed. The others delivered at night or on weekends and destroyed the pups. Of the surviving pups, the average weight was 61 grams per pup (Table 1).

Average blood glucose concentrations for each weekly turnover rate study are presented in Table 2 . In non-pregnant rabbits, glucose concentration did not vary significantly with time $(P>$ 0.1 ). In pregnant rabbits, glucose concentration fell by the end 
Table 1. Weights $(\mathrm{kg})$

\begin{tabular}{|c|c|c|c|c|c|}
\hline \multirow[b]{2}{*}{ Animals } & \multicolumn{5}{|c|}{ Weekly study number } \\
\hline & N-P* & 1 & 2 & 3 & 4 \\
\hline \multicolumn{6}{|l|}{ N-P rabbits } \\
\hline $\bar{x}$ & & 3.44 & 3.22 & 3.27 & 3.50 \\
\hline SEM & & 0.15 & 0.08 & 0.12 & 0.09 \\
\hline$n$ & & 11 & 8 & 7 & 4 \\
\hline \multicolumn{6}{|l|}{ Pregnant rabbits } \\
\hline $\bar{x}$ & 3.82 & 3.83 & 3.89 & 3.93 & 4.19 \\
\hline SEM & 0.20 & 0.16 & 0.20 & 0.23 & 0.26 \\
\hline$n$ & 9 & 11 & 8 & 7 & 5 \\
\hline \multicolumn{6}{|l|}{ Offspring } \\
\hline Average litter size, & \multicolumn{5}{|c|}{4.9 pups } \\
\hline Average litter weight, & \multicolumn{5}{|l|}{$300 \mathrm{~g}$} \\
\hline Average weight per pup, & \multicolumn{5}{|l|}{$61 \mathrm{~g}$} \\
\hline
\end{tabular}

${ }^{*} \mathrm{~N}-\mathrm{P}$, non-pregnant.

Table 2. Blood glucose concentrations $(\mathrm{mg} / \mathrm{dl})$

\begin{tabular}{lccccc}
\hline & \multicolumn{5}{c}{ Weekly study number } \\
\cline { 2 - 6 } \multicolumn{1}{c}{ Animals } & N-P* & 1 & 2 & 3 & 4 \\
\hline N-P rabbits & & & & & \\
$\quad \bar{x}$ & & 91.5 & 94.5 & 91.2 & 84.0 \\
SEM & & 1.7 & 3.5 & 2.0 & 2.1 \\
$n$ & & 11 & 8 & 7 & 4 \\
Pregnant rabbits & & & & & \\
$\quad \bar{x}$ & 88.2 & 90.4 & 85.3 & 80.7 & 74.6 \\
SEM & 2.0 & 2.2 & 1.6 & 1.6 & 2.7 \\
$n$ & 9 & 11 & 7 & 7 & 5 \\
\hline
\end{tabular}

* N-P, non-pregnant.

Table 3. Glucose turnover rates $\left(\mathrm{mg} \cdot \mathrm{min}^{-1} \cdot \mathrm{kg}^{-1}\right)$

\begin{tabular}{llllll}
\hline & \multicolumn{5}{c}{ Weekly study number } \\
\cline { 2 - 6 } Animals & N-P* & 1 & 2 & 3 & \multicolumn{1}{c}{4} \\
\hline N-P rabbits & & & & & \\
U-[ ${ }^{14}$ C]-glucose & & & & & \\
$\bar{x}$ & & 4.93 & 4.59 & 4.40 & 3.98 \\
SEM & & 0.45 & 0.52 & 0.30 & 0.34 \\
$n$ & & 11 & 8 & 7 & 4 \\
6-[ $\left.{ }^{3} \mathrm{H}\right]$-glucose & & & & & \\
$\bar{x}$ & & 5.25 & 5.01 & 4.81 & 4.55 \\
SEM & & 0.39 & 0.61 & 0.39 & 0.43 \\
$n$ & & 11 & 8 & 7 & 4 \\
Pregnant rabbits & & & & & \\
U-[ $\left.{ }^{14} \mathrm{C}\right]$-glucose & & & & & \\
$\bar{x}$ & 3.50 & 3.74 & 3.64 & 4.06 & 3.50 \\
SEM & 0.18 & 0.15 & 0.29 & 0.47 & 0.19 \\
$n$ & 9 & 11 & 7 & 7 & 5 \\
6-[ $\left.{ }^{3} \mathrm{H}\right]$-glucose & & & & & \\
$\bar{x}$ & 3.68 & 4.05 & 3.99 & 4.44 & 3.86 \\
SEM & 0.25 & 0.19 & 0.35 & 0.51 & 0.19 \\
$n$ & 9 & 11 & 7 & 7 & 5 \\
\hline
\end{tabular}

*N-P, non-pregnant.

of gestation to an average value of $74.6 \pm 2.7 \mathrm{mg} / \mathrm{dl}$, significantly less than the average non-pregnant value of $88.2 \pm 2.4 \mathrm{mg} / \mathrm{dl}$ for these same rabbits, $(P>0.01)$. The mean intra-animal coefficient of variation for glucose concentration over time was $5.8 \%$ for the non-pregnant group and was $6.5 \%$ for the pregnant group.

Glucose turnover rates are presented in Table 3. Glucose turnover rate did not vary significantly with time in both the non-pregnant and the pregnant groups. The mean intra-animal coefficient of variation for glucose turnover rates over time were $12.3 \%\left(\left[{ }^{14} \mathrm{C}\right]\right.$ calculations $)$ and $13.3 \%\left(\left[{ }^{3} \mathrm{H}\right]\right.$ calculations $)$ for the non-pregnant group and were $11.0 \%\left(\left[{ }^{14} \mathrm{C}\right]\right.$ calculations $)$ and $11.1 \%\left(\left[{ }^{3} \mathrm{H}\right]\right.$ calculations) for the pregnant group. Percentage carbon recycling was identical for both groups $(8.0 \%$ for nonpregnant, $9.0 \%$ for pregnant) and did not vary significantly during pregnancy.

Glucose turnover rates, calculated as an average of the $\left[{ }^{14} \mathrm{C}\right]$ and the $\left[{ }^{3} \mathrm{H}\right]$ glucose values, are compared with average blood glucose values for each study in Figure 1. Glucose turnover rate in non-pregnant animals was linearly related to blood glucose concentration $(\mathrm{y}=0.127 \mathrm{x}-6.96, r=0.71, P<0.001)$. This relationship was not evident in pregnant animals $(r=0.13, P>$ 0.5 ). Non-linear regressions (logarithmic, power, exponential) for the pregnant group failed to improve the correlation.

Glucose clearance increased during the latter part of pregnancy and was due entirely to the fall in glucose concentration. At term the clearance was significantly higher in pregnant than in nonpregnant animals, $\left(7.0 \mathrm{ml} \cdot \mathrm{min}^{-1} \cdot \mathrm{kg}^{-0.75}\right.$ versus $6.0 \mathrm{ml} \cdot \mathrm{mg}^{-1}$. $\left.\mathrm{kg}^{-0.75}, P<0.05\right)$.

\section{DISCUSSION}

The present report describes a small animal model which permits metabolic rate measurements such as glucose turnover rates in the same animal both before and throughout pregnancy. The relatively low coefficients of correlation for weight, glucose concentration, and glucose turnover rate, and the close approximation of these values for the non-pregnant and the pregnant animals suggest that these animals and the described methodology are suitable for chronic studies during pregnancy. Such investigations should help to define more precisely the timing and magnitude of the impact of pregnancy on maternal glucose metabolism.

Several earlier investigations of glucose turnover rates in rabbits have been reported. In 1959, Berson et al. (4) reported on acute experiments in unanesthetized rabbits in which a bolus injection of $\left[\mathrm{U}_{-}^{14} \mathrm{C}\right] \mathrm{glucose}$ was made into an ear vein with blood sampling from another ear vein. Glucose turnover rates averaged

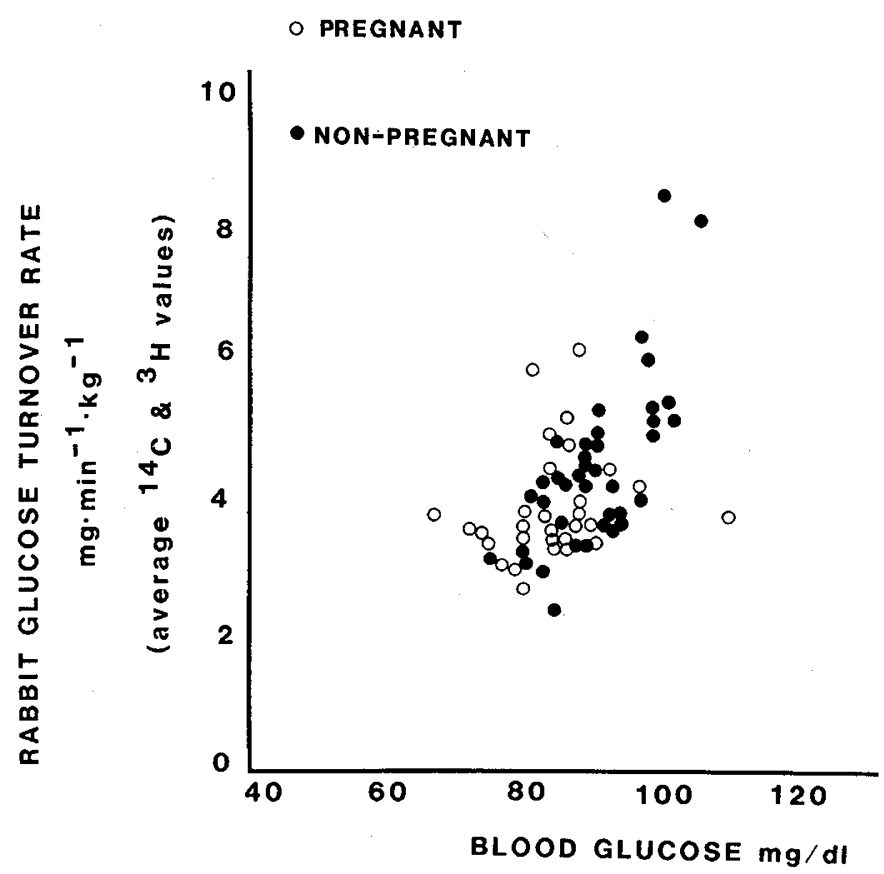

Fig. 1. Glucose turnover rate (average of the $U-\left[{ }^{14} \mathrm{C}\right]$ and the $6-\left[{ }^{3} \mathrm{H}\right]$ values) is compared with blood glucose concentration in non-pregnant $(\mathrm{y}=0.127 \mathrm{x}-6.96 ; r=0.71, P<0.001)$ and pregnant $(r=0.13, P>$ $0.5)$ animals. 


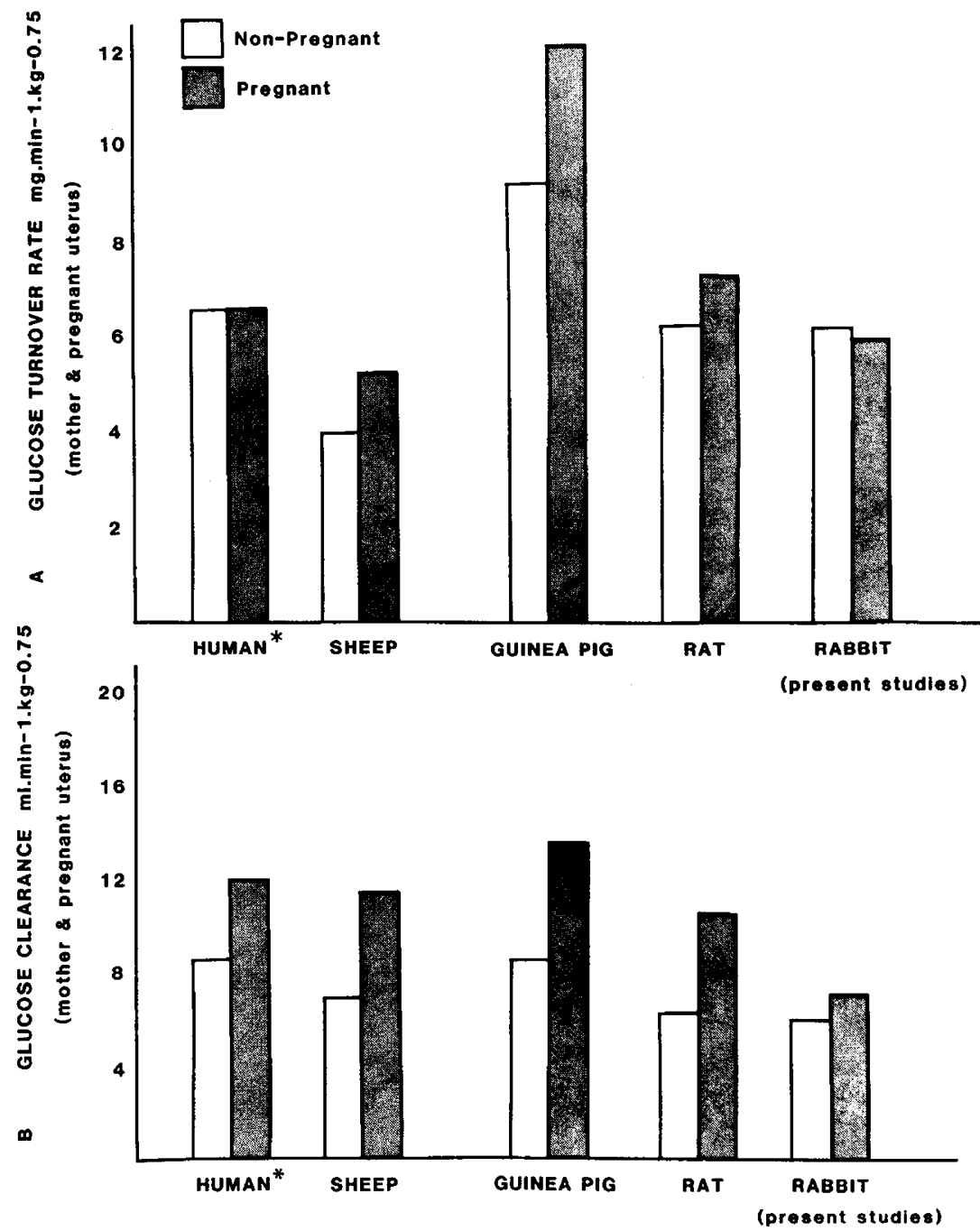

Fig. 2. (A) Non-pregnant and pregnant weight-specific glucose turnover rates expressed as $\mathrm{mg} \cdot \mathrm{min}^{-1} \cdot \mathrm{kg}^{-0.75}$ are shown for humans (*weights estimated at $55 \mathrm{~kg}$ for non-pregnant women and $65 \mathrm{~kg}$ for pregnant women) (10), sheep (2) (3), guinea pigs (7), rats (14), and rabbits (present studies). (B) Weight specific maternal glucose clearance values (glucose turnover rate $\div$ blood glucose concentration, expressed in $\mathrm{ml} \cdot \mathrm{min}^{-1} \cdot \mathrm{kg}^{-0.75}$ ) are shown for humans (10), sheep (2) (3), guinea pigs (7), rats (14), and pregnant rabbits with three or more weekly studies from the present report.

$1.3-2.0 \mathrm{mg} \cdot \mathrm{min}^{-1} \cdot \mathrm{kg}^{-1}$, and were increased with glucose and insulin injections. Baseline glucose concentrations in these animals were relatively stable, but higher than those of the present report, averaging about $110 \mathrm{mg} / \mathrm{dl}$.

In $1974 \mathrm{Katz}$ et al. (11) and in 1976 Dunn et al. (5) reported experiments on conscious, catheterized rabbits, which were studied 3-4 d postsurgery. Their animals were fasted overnight before study. In the first report, their rabbits were hyperglycemic $(\bar{x}=$ $141.4 \mathrm{mg} / \mathrm{dl}$ of plasma) compared with our non-pregnant rabbits. Glucose turnover rates were approximately $4 \mathrm{mg} \cdot \mathrm{min}^{-1} \cdot \mathrm{kg}^{-1}$ (range, $3-4.5 \mathrm{mg} \cdot \mathrm{min}^{-1} \cdot \mathrm{kg}^{-1}$ ) and $10-35 \%$ of the glucose carbon was recycled, depending upon whether $\left[{ }^{3} \mathrm{H}\right]$ glucose labeled at the 2 nd or at the 6 th carbon was compared with $\left[\mathrm{U}-{ }^{14} \mathrm{C}\right]$ glucose.

In 1980, Atkin's reported experiments in which rabbits were studied weekly up to $4 \mathrm{wk}$, although ear vein cannulation for infusion and sampling was performed as an acute procedure for each study and the rabbits were fasted $18 \mathrm{~h}$ before study (1). Glucose values averaged about $110-120 \mathrm{mg} / \mathrm{dl}$ and glucose turnover rates averaged $3.30 \pm 0.24 \mathrm{mg} \cdot \mathrm{min}^{-1} \cdot \mathrm{kg}^{-1}$.

In the present study both maternal weight and glucose turnover rate did not increase with pregnancy. These observations suggest that pregnant rabbits supply glucose to their conceptus at the expense of their own tissues. This point is further supported by the relationship between maternal glucose concentration and glucose turnover rate shown in Figure 1. As pregnancy progresses, glucose concentration falls. In non-pregnant animals glucose turnover rate decreases directly with glucose concentration. The glucose concentration which we found at term in pregnant rabbits ( $75 \mathrm{mg} / \mathrm{dl}$ ) would correspond to a glucose turnover rate in nonpregnant rabbits of about $2.5 \mathrm{mg} \cdot \mathrm{min}^{-1} \cdot \mathrm{kg}^{-1}$ leaving approximately $4-6 \mathrm{mg} \cdot \mathrm{min}^{-1}$ for glucose utilization by the pregnant uterus at term. The question of whether there is a shift to the utilization of alternate fuels rather than glucose by the nonuterine tissues of the pregnant rabbit requires further testing.

Only a few studies of maternal glucose turnover rates during pregnancy in other mammals have been reported. These include measurements in man, sheep, guinea pig, and rat. For comparative purposes the data for these species are presented in Figure $2 \mathrm{~A}$. The turnover rates are expressed to the $3 / 4$ power of body weight as several studies of oxidative metabolism for a number of substrates in a variety of species have demonstrated that metabolic rates are most highly correlated with the body weight expressed to the 0.75 power (13). In all these species glucose turnover rate, expressed on a weight specific basis, is either unchanged or increased with pregnancy. Because part of the uterine weight (amniotic fluid, and/or allantoic fluid) is nonmetabolizing tissue, these observations imply a higher weight specific glucose utilization rate by the conceptus compared with 
the rest of the non-uterine maternal tissues. For example, Kalhan et al. (10) found no difference between the weight specific glucose turnover rate of non-pregnant women and of pregnant women $\left(6.62\right.$ and $\left.6.63 \mathrm{mg} \cdot \mathrm{min}^{-1} \cdot \mathrm{kg}^{-0.75}\right)$. In sheep we have made direct measurements of glucose uptake by the uterus as a whole and by the conceptus $(8,9)$. These measurements illustrate a 2.3-fold higher weight specific rate of glucose utilization by the fetal lamb than the mother and a 36-fold higher weight specific glucose utilization rate by the uteroplacental tissues compared with the mother. Supporting these direct measurements of glucose utilization by the conceptus, Bergman (2) reported a $63 \%$ absolute increase or $33 \%$ weight specific increase in glucose turnover rate between non-pregnant and twin-pregnant sheep. In pregnant guinea pigs, Gilbert et al. (7) reported a constant weight specific glucose turnover rate for animals with different gestational ages. In these guinea pigs total maternal weight averaged $50 \%$ greater for near-term animals compared with early pregnant animals whereas the glucose turnover rate at term $(60 \mathrm{~d})$ was about $73 \%$ greater than turnover rates in non-pregnant animals and about $50 \%$ greater than turnover rates in early pregnant (30 d) animals.

The increased glucose clearance (Fig. 2B), which occurred in late pregnancy, was inversely related to the lower glucose concentration. Similar observations for both glucose clearance and glucose concentration have been made in pregnant rats, guinea pigs, sheep and humans; thus, an increasing maternal glucose clearance appears to be a general characteristic of mammalian maternal metabolism. The reasons for the fall in maternal glucose concentration in late pregnancy have not been determined. Because it is a sustained phenomenon, it must involve a change in the set point for physiologic regulation of glucose concentration.

The present report describes relatively low glucose carbon recycling rates of $8-9 \%$, which did not change with increasing gestational age. Dunn et al. (5) reported mean carbon recycling values of $19-29 \%$ (range, 10-37\%) in rabbits. The lower carbon recycling values were calculated from $\left[\mathrm{U}-{ }^{14} \mathrm{C}\right]$ glucose compared with turnover rates derived from $\left[3-{ }^{3} \mathrm{H}\right]-$ or $\left[6-{ }^{3} \mathrm{H}\right] \mathrm{glucose}$; the higher values were calculated from comparison of turnover rates derived from $\left[\mathrm{U}-{ }^{14} \mathrm{C}\right]$ glucose and $\left[3-{ }^{3} \mathrm{H}\right]-$ or $\left[6-{ }^{3} \mathrm{H}\right] \mathrm{glucose}$. The percentage carbon recycling values derived from $\left[\mathrm{U}_{-}{ }^{14} \mathrm{C}\right] \mathrm{glucose}$ versus $\left[3-{ }^{3} \mathrm{H}\right]-$ or $\left[6-{ }^{3} \mathrm{H}\right]$ glucose tracers are considered to more accurately reflect true carbon recycling as these tritium labels are lost proportionate to the irreversible metabolism of glucose. Tritium labels on the 2 nd and 5 th glucose carbons can be lost in excess of glucose molecules by futile cycling leading to a falsely elevated turnover rate and percentage carbon recycling (12). Also, the studies by Dunn et al. (5) were carried out on fasted animals and it is possible that increased rates of gluconeogenesis occurred during fasting, which could produce a more rapid carbon recy- cling especially for single injection or short-term tracer infusion studies. In pregnant guinea pigs glucose carbon recycling increased with advancing gestation, perhaps reflecting the impact of the enlarging uterine mass (7). In both non-pregnant and pregnant rats (14) glucose carbon recycling averaged about $25 \%$ whereas in non-pregnant sheep (2) and in fetal lambs (9) glucose carbon recycling is negligible, even under conditions leading to fetal gluconeogenesis.

\section{REFERENCES AND NOTES}

1. Atkins, G. L.: A new technique for maintaining and monitoring conscious, stress-free rabbits in a steady state: its use in the determination of glucose kinetics. Quart. J. Exper. Physiol., 65: 64 (1980).

2. Bergman, E. N.: Quantitative aspects of glucose metabolism in pregnant and non-pregnant sheep. Am. J. Physiol., 204: 147 (1963).

3. Bergman, E. N. and Hogue, D. E.: Glucose turnover and oxidation rates in lactating sheep. Am. J. Physiol., 213: 1378 (1967).

4. Berson, S. A., Weisenfeid, S., and Pascuelo, M.: Utilization of glucose in normal and diabetic rabbits. Diabetes, 8: 116 (1959).

5. Dunn, A., Katz, J., Golden, S., and Chenoweth, M.: Estimation of glucose turnover and recycling in rabbits using various $\left({ }^{3} \mathrm{H},{ }^{14} \mathrm{C}\right)$ glucose labels. Am. J. Physiol., 230: 1159 (1976).

6. Gilbert, M., Hay, W. W., Jr., Johnson, R. L., and Battaglia, F. C.: Some aspects of maternal metabolism throughout pregnancy in the conscious rabbit, submitted for publication (1982).

7. Gilbert, M., Sparks, J. W., Girard, J., and Battaglia, F. C.: Glucose turnover rate during pregnancy in the conscious guinea pig. Pediatr. Res., 16: 310 (1982).

8. Hay, W. W., Jr., Sparks, J. W., Wilkening, R. B., Battaglia, F. C., and Meschia, G.: Partition of maternal glucose production between conceptus and maternal tissues in sheep. Am. J. Physiol., 245: E347 (1983).

9. Hay, W. W., Jr., Sparks, J. W., Quissell, B. J., Battaglia, F. C., and Meschia, G.: Simultaneous measurements of umbilical uptake, fetal utilization rate and fetal turnover rate of glucose. Am. J. Physiol., 40: E662 (1981).

10. Kalhan, S. C., D'angelo, L. J., Savin, S. M., and Adam, P. A. J.: Glucose production in pregnant women at term. J. Clin. Invest., 63: 338 (1979).

11. Katz, J., Dunn, A., Chenoweth, M., and Golden, S.: Determination of synthesis, recycling and body mass of glucose in rats and rabbits in vivo with ${ }^{3} \mathrm{H}$ and ${ }^{14} \mathrm{C}$-labelled glucose. Biochem. J., I42: 171 (1974).

12. Katz, J. and Rognstad, R.: Futile cycles in the metabolism of glucose. Curr. Top. Cell. Regul., 10: 237 (1976).

13. Kleiber, M.: Body size and metabolic rate. Physiol. Rev., 27: 511 (1947).

14. Leturque, A., Gilbert, M., and Girard, J.: Glucose turnover during pregnancy in anaesthetized post-absorptive rats. Biochem. J., 196: 633 (1981).

15. Sparks, J. W., Pegorier, J. P., Girard, J., and Battaglia, F. C.: Substrate concentration changes during pregnancy in the guinea pig studied under unstressed steady state conditions. Pediatr. Res., 15: 1340 (1981).

16. Dr. Hay is the recipient of a Special Emphasis Research Career Award (Diabetes Mellitus: Pediatric Aspects), NIH-NIADDK-NICHD.

17. Dr. Johnson was supported by NIH Training Grant \#HD 07186.

18. Requests for reprints should be addressed to: Dr. William W. Hay, Jr., Associate Professor of Pediatrics, Box B195 Division of Perinatal Medicine, University of Colorado School of Medicine, 4200 East Ninth Avenue, Denver, Colorado 80262 .

19. This research was supported by NIH Program Grant HD 00781.

20. Received for publication November 12, 1982.

21. Accepted for publication June 3, 1983. 